Original Research Paper

\title{
Penguatan Kapasitas Dalam Perencanaan dan Pengembangan Usaha Hasil Hutan Bukan Kayu (HHBK) Bagi Petani Pesanggem Hutan Kemasyarakatan (HKm) Sesaot Lombok Barat
}

\author{
L. Sukardi ${ }^{1}$, M. Husni Idris ${ }^{2}$ Bambang Dipokusumo $^{1}$ \\ ${ }^{1}$ Jurusan Sosial Ekonomi Pertanian, Fakultas Pertanian Universitas Mataram, Mataram, Indonesia; \\ ${ }^{2}$ Jurusan Kehutanan, Fakultas Pertanian Universitas Mataram, Mataram, Indonesia;
}

https://doi.org/10.29303/jpmpi.v3i2.937

Sitasi: Sukardi, L., Idris, M. H., \& Dipokusumo, B. (2021). Penguatan Kapasitas Dalam Perencanaan dan Pengembangan Usaha Hasil Hutan Bukan Kayu (HHBK) Bagi Petani Pesanggem Hutan Kemasyarakatan (HKm) Sesaot Lombok Barat. Jurnal Pengabdian Magister Pendidikan IPA, 4(3)

\author{
Article history \\ Received: 31 Juli 2021 \\ Revised: 31 Agustus 2021 \\ Accepted: 4 September 2021 \\ *Corresponding Author: L. \\ Sukardi, Jurusan Sosial \\ Ekonomi Pertanian, Fakultas \\ Pertanian Universitas Mataram, \\ Mataram, Indonesia; \\ Email: 1sukardi@unram.ac.id
}

\section{Pendahuluan}

Pengelolaan hutan yang menguntungkan secara sosial membantu baik penduduk lokal dan masyarakat pada umumnya untuk menikmati manfaat jangka panjang dan juga memberikan insentif yang kuat bagi penduduk lokal untuk mempertahankan sumberdaya hutan dan mematuhi rencana pengelolaan jangka panjang. Sementara itu, pengelolaan hutan yang berkesinambungan secara ekonomi berarti bahwa kegiatan kehutanan terstruktur dan dikelola sehingga menjadi cukup menguntungkan. Dalam hal ini keuntungan finansial tidak dilakukan dengan cara mengorbankan sumber daya hutan, ekosistem, atau masyarakat. Tekanan antara kebutuhan untuk menghasilkan keuntungan keuangan yang mencukupi dan prinsip-prinsip kegiatan kehutanan yang bertanggung jawab, dapat dikurangi melalui upaya untuk memasarkan berbagai produk dan jasa hutan berdasarkan nilai terbaik mereka (Anggaran Dasar FSC, diratifikasi, September 1994; revisi terakhir pada Juni 2011).

Salah satu upaya untuk mengoptimalkan peningkatan kapasitas masyarakat dalam pengelolaan hutan berkelanjutan sesuai dengan prinsip-prinsip yang terdapat dalam FSC adalah penguatan kapasitas usaha bagi masyarakat, terutama berkenaan dengan kemampuannya merencanakan dan mengembangkan usaha ekonomi produktif berbasis hasil hutan bukan kayu (HHBK).

Usaha agribisnis HHBK di wilayah Sesaot pada dasarnya memberikan peluang bagi anggota masyarakat pedesaan untuk menggunakan potensi kapital yang ada di wilayahnya sendiri serta memanfaatkan peluang bisnis yang ada. Dengan demikian anggota masyarakat (khususnya petani 
$\mathrm{HKm})$ mempunyai peluang untuk memanfaatkan potensi ekonomi baik dalam kegiatan "On Farm" maupun pada kegiatan "Off Farm" seperti pada usaha pengolahan hasil, pemasaran dan jasa lainnya.

Sesuai dengan tuntutan pembangunan kedepan guna dapat mensejahterakan masyarakat di wilayah Sesaot khususnya, maka potensi kawasan perlu dikembangkan secara optimal melalui pendekatan agribisnis sesuai dengan komoditas unggulannya. Untuk itu perlu peningkatan kapasitas petani dalam mengelola kawasan $\mathrm{HKm}$ secara optimal. Oleh karena itu perlu "Pelatihan Perencanaan dan Pengembangan Usaha Berbasis Hasil Hutan Bukan Kayu (HHBK) Bagi Petani Pesanggem Hutan Kemasyarakatan (Hkm) Sesaot Lombok Barat".

Tujuan dari kegiatan "Pelatihan Perencanaan dan Pengembangan Usaha Hasil Hutan Bukan Kayu (HHBK) bagi Petani Pesanggem Hutan Kemasyarakatan (HKm) Sesaot Lombok Barat" ini adalah (1) Meningkatkan pemahaman dan kesadaran peserta tentang pentingnya perencanaan usaha sebagai instrumen untuk mengelola usaha, serta unsur-unsur penting dalam penyusunan rencana usaha HHBK, (2) Meningkatkan kemampuan peserta dalam mengidentifikasi dan melakukan pemilihan bidang usaha HHBK prioritas, (3) Meningkatkan kemampuan dan keterampilan peserta dalam menyusun rencana usaha HHBK.

Dengan adanya kegiatan pelatihan ini, diharapkan kepada para petani pesanggem di HKm Sesaot dapat menyusun merencanakan dan mengembangkan usaha HHBK yang potensial dan memiliki prospek ekonomi. Dengan demikian, para petani pesanggem dapat lebih terarah dalam memilih komoditi dan jenis usaha yang menguntungkan untuk meningkatkan pendapatan keluarga.

\section{Metode}

Pemecahan masalah yang diterapkan oleh tim penyuluh adalah: pertama-tama melakukan studi pendahuluan ke desa setempat. Kunjungan bertujuan untuk melihat kondisi terakhir wilayah dan gambaran umum aktivitas calon kelompok sasaran sekaligus menyampaikan maksud dan tujuan tim untuk melakukan kegiatan penyuluhan/pelatihan. Dalam pertemuan antara tim dengan perwakilan kelapa desa dan pengurus kelompok disepakati hal-hal sebagai berikut: Waktu dan tempat pelaksanaan penyuluhan/pelatihan, peserta penyuluhan/pelatihan, dan pembiayaan kegiatan.

Sasaran antara yang strategis dari kegiatan penyuluhan dan pelatihan ini adalah para pengurus kelompok $\mathrm{HKm}$ serta perwakilan kelompok masyarakat dan pelaku usaha ekonomi di bidang agribisnis dan/atau agroindustri HHBK di Desa Sesaot, Kecamatan Narmada, Kabupaten Lombok Barat.

Kegiatan penyuluhan diawali dengan pengarahan oleh perwakilan Kepala Desa Sesaot dan ketua kelompok HKm. Selanjutnya ketua tim penyuluh memperkenalkan anggota tim penyuluh/pelatih yang terdiri atas 3 orang. Selanjutnya masing-masing anggota tim secara bergiliran menyampaikan materi yang berkaitan dengan perencanaan usaha HHBK sesuai dengan jadwal yang telah disepakati. Kegiatan ini dilakukan dalam bentuk penyuluhan dan simulasi serta pemutaran film dan dilanjutkan dengan diskusi.

Materi disampaikan dengan bahasa yang paling dimengerti oleh peserta, termasuk menggunakan Bahasa Sasak. Simulasi juga dilakukan dengan membagikan peserta form isian yang berisi tentang perencanaan usaha. Selain penyampaian materi dan simulasi, tim penyuluh juga melakukan pemutaran film dan testimoni tentang kiat-kiat sukses pengembangan usaha kecil di pedesaan. Setelah materi disampaikan secara keseluruhan berikut pemutaran film, kegiatan penyuluhan dilanjutkan dengan diskusi dan tanya jawab. Materi penyuluhan ini terdiri atas 4 (empat) pokok bahasan, yaitu:

1. Pentingnya Perencanaan Usaha

2. Unsur-Unsur Penting Dalam Penyusunan Rencana Usaha HHBK

3. Pemilihan Bidang Usaha HHBK

4. Menyusun Rencana Usaha HHBK

\section{Hasil dan Pembahasan}

Berdasarkan hasil kegiatan dan evaluasi yang dilakukan baik pada saat penyampaian materi maupun setelah penyampaian materi, ditemukan indikasi yang menunjukkan keberhasilan kegiatan penyuluhan ini baik bagi tim penyuluh maupun 
peserta penyuluhan sebagai kelompok sasaran; tercermin dari beberapa hal sebagai berikut:

1. Meningkatnya pemahaman peserta tentang pengertian dan pentingnya perencanaan usaha sebagai instrumen untuk mengelola usaha HHBK

2. Meningkatnya pemahaman peserta tentang unsur-unsur dan pertimbangan-pertimbangan dalam penyusunan rencana usaha

3. Meningkatnya kemampuan peserta dalam melakukan pemilihan bidang usaha HHBK

4. Meningkatnya kemampuan dan keterampilan peserta dalam menyusun rencana usaha berbasis HHBK.

\section{Faktor Penghambat}

Pada dasarnya seluruh rangkaian kegiatan penyuluhan ini, mulai dari perencanaan hingga pelaksanaan di lapangan, secara umum dapat dikatakan berjalan dengan lancar dan sukses. Meski demikian terdapat beberapa hal yang perlu disikapi dengan lebih hati-hati.

Hambatan utama adalah perbedaan latar belakang pendidikan dan pengetahuan, umur, serta kondisi sosial ekonomi di antara peserta. Hal ini membutuhkan kesabaran dan kemampuan tim penyuluh untuk menyesuaikan diri dengan kondisi dan situasi tersebut. Perbedaan tingkat pengetahuan peserta ini sangat berpengaruh terhadap daya serapnya terhadap materi yang disampaikan, terutama sekali pada saat penyampaian materi yang berhubungan dengan perhitungan kelayakan usaha dan manajemen keuangan.

\section{Faktor Pendorong}

Kegiatan pengabdian kepada masyarakat ini dapat terlaksana karena beberapa faktor pendorong, diantaranya yang terpenting adalah:

1. Adanya sikap ingin tahu serta keinginan untuk maju dan berkembang (progresif) dari para peserta; mendorong mereka untuk tekun dan serius mengikuti dan mendengarkan semua materi yang disuluhkan. Hal ini ditunjukkan oleh sikap kritis mereka dalam menanggapi setiap point dari materi penyuluhan tersebut dan keinginan untuk mendapatkan jawaban yang logis dari setiap pertanyaan yang dilontarkan. Selain itu peserta dengan tanpa ragu-ragu menyampaikan permasalahan yang dihadapi dalam kelompok tani.
2. Kondisi lokasi penyuluhan dan profesi kelompok sasaran yang sangat mendukung dan sesuai dengan materi yang disuluhkan.

3. Kerjasama dan bantuan dari pemerintah desa setempat sangat mendukung pelaksanaan kegiatan ini. Hal ini terlihat dari keseriusan aparat desa setempat dalam mengumpulkan peserta dan menyediakan tempat penyuluhan berlangsung. Selain itu karyawan dan tokoh masyarakat di lokasi penyuluhan juga sangat membantu dalam menjelaskan materi yang kirakira kurang dimengerti dalam bahasa Indonesia.

\section{Evaluasi}

Berdasarkan pengamatan yang dilakukan pada saat pelaksanaan kegiatan penyuluhan di lapangan, kegiatan ini dapat dikatakan cukup berhasil. Hal ini tercermin dari kesungguhan atau keseriusan peserta penyuluhan dalam mengikuti dan menanggapi setiap materi yang diberikan. Keadaan ini sekaligus merupakan indikator adanya relevansi yang kuat antara pokok materi dengan kebutuhan atau masalah yang dihadapi oleh peserta penyuluhan.

Apresiasi yang ditunjukkan oleh peserta penyuluhan sebagaimana dijelaskan di atas, hanya dapat digunakan sebagai petunjuk adanya perubahan wawasan dan pola pikir para peserta penyuluhan. Akan tetapi belum dapat dijadikan indikator untuk rnengetahui apakah materi yang disuluhkan benar-benar akan diterapkan oleh peserta.

Selanjutnya hal penting yang dirasakan baik oleh penyuluh maupun peserta penyuluhan adalah ketika ingin mengimplementasikan materi yang disuluhkan, yaitu menyangkut perencanaan usaha HHBK. Di sisi lain, pendanaan dari kegiatan penyuluhan/pelatihan ini terbatas sehingga kegiatan yang dilakukan hanya sebatas penyampaian materi penyuluhan/pelatihan saja. Dengan perkataan lain, tidak bisa dilakukan pendampingan kepada peserta pelatihan dalam praktek pelaksanaan atau implementasi dari materi yang disuluhkan.

\section{Kesimpulan}

Berkenaan dengan kegiatan penyuluhan/pelatihan yang telah dilakukan, dapat disimpulkan hal-hal sebagai berikut:

1. Kegiatan penyuluhan/pelatihan dapat meningkatkan kesadaran pengurus, anggota 
kelompok HKm dan/atau masyarakat lainnya akan pentingnya perencanaan usaha HHBK. Apresiasi yang ditunjukkan oleh peserta penyuluhan dapat digunakan sebagai petunjuk adanya perubahan wawasan dan pola pikir para peserta penyuluhan.

2. Faktor pendorong dari keberhasilan kegiatan penyuluhan/pelatihan ini adalah adanya sikap ingin tahu serta keinginan untuk maju dan berkembang (progresif) dari para peserta; ditunjukkan oleh sikap kritis mereka dalam menanggapi setiap point dari materi penyuluhan tersebut dan keinginan untuk mendapatkan jawaban yang logis dari setiap pertanyaan yang dilontarkan.

\section{Daftar Pustaka}

Ambadar, J. Miranty Abidin, dan Yanty Isa, 2005. Mulai Usaha dari Nol. Yayasan Bina Karsa Mandiri.

Anonymous, 2012. Modul Kewirausahaan. Menyusun Business Plan bagi Wirausaha Pemula. Jakarta: Kementerian Koperasi dan UMKM.

Arto, Pudji, 2013. Analisis Kelayakan Usaha Agribisnis. http:/pujiart.blogspot.com. Diakses 18 Nopember 2013.

Hailes, Jr., W. D and R. T. Hubbard, 1983. Small Business Management: Planning and Operation. New York: Van Nostrand Reinhold.

Haryati La Kamisi, 2011. Analisis Usaha dan Nilai Tambah Agroindustri Kerupuk Singkong. Jurnal Ilmiah Agribisnis dan Perikanan (Agrikan UMMU-Ternate) 4 (2):82-87.

Marimin, 2004. Pengambilan Keputusan Kriteria Majemuk. Teknik dan Aplikasi. PT. Gramedia Widiasarana Indonesia. Jakarta.

Pinson, L. and J. Jinnett. 1993. Anatomy of a Business Plan. Dearborn Publishing Co.

Poteet, G. H., 1991. Starting Up Your Own Business--Expert Advice from the U.S. Small Business Administration. Blue Ridge Summit, PA, The Liberty Hall Pres.
Pusdiklat

Kehutanan, 2015. http://pusdiklathut.org/baktirimbawan/anali sa usahatani/index. $\mathrm{html}$

Rangkuti, Freddy, 1997. Analisis SWOT: Teknik Membedah Kasus BisnisReorientasi

Reni Kustiari, 2011. Analisis Nilai Tambah dan Balas Jasa Faktor Produksi Pengolahan Hasil Pertanian. Makalah disampaikan dalam Seminar Nasional Petani dan Pembangunan Pertanian di Bogor, 12 Oktober 2011.

Sarosa, P., 2003. Seri Kiat Praktis Membuka Usaha: Langkah Awal menjadi Entrepreneur Sukses. PT. Elex Media Komputindo.

Shane, S., 2003. A General Theory of Entrepreneurship.the Individualopportunity Nexus.USA: Edward Elgar

Slamet, U., 2005. Nilai Tambah dan Balas Jasa Faktor Produksi Pengolahan Hasil-hasil Pertanian. Bulletin penelitian Nomor 8:1-8.

Soekartawi, 1995. Analisis Usahatani, Universitas Indonesia, Jakarta.

Suparyanto, Wahyu, 2004. Mudah Menyusun Studi Kelayakan Usaha. Bandung: Penerbit Alfabeta.

Suprapto, A. 1999. Pengembangan Agribisnis Komoditas Unggulan dalam memasuki Pasar Global. Makalah disampaikan dalam Lokakarya Nasional Musyawarah Nasional V POPM

Suryana, 2003. Kewirausahaan. Cetakan keempat. Jakarta. Penerbit Salemba Empat. 